\title{
SIMULATION OF SEISMIC RESPONSE OF REINFORCED CONCRETE BEAM-COLUMN JOINTS WITH NURBS SURFACE FITTING
}

\section{R. TABATABAEI MIRHOSSEINI ${ }^{1}$}

\begin{abstract}
This paper presents an approach based on NURBS (non-uniform rational B-splines) to achieve a seismic response surface (SRS) from a group of points obtained by using an analytical model of RC joints. NURBS based on the genetic algorithm is an important mathematical tool and consists of generalizations of Bezier curves and surfaces and B-splines. Generally, the accuracy of the design process of joints depends on the number of control points that are captured in the results of experimental research on real specimens. The values obtained from the specimens are the best tools to use in seismic analysis, though more expensive when compared to values simulated by SRSs. The SRS proposed in this paper can be applied to obtain surfaces that show site effect results on destructions of beam-column joint, taking into account different site conditions for a specific earthquake. The efficiency of this approach is demonstrated by the retrieval of simulated-versus-analytical results.
\end{abstract}

Keywords: B-spline, NURBS, seismic response surface (SRS), RC joint, analytical model, genetic algorithm, tectonic characteristics

\section{INTRODUCTION}

RC beam-column joints are considered to be a very important component of energy transmission in reinforced concrete frames. A review of the damage assessment of reinforced concrete structures proves the importance of consideration of the joint as an important factor involved in the collapse mechanism [1]. Since past research shows that tectonic characteristics could be effective on damage of structures, a fact underestimated by many engineers during the design process, since joints are the

\footnotetext{
${ }^{1}$ Associate Prof., Islamic Azad University, Kerman Branch, Civil Engineering Dept., Postal Code 7635131167,

Kerman, Iran, e-mail: tabatabaei@iauk.ac.ir
} 
most important component of a structure, ongoing research in this field is seriously required. Beams must be designed in such a way that plastic hinges within move away from the joint region as much as possible. For joints with sufficient strength which develops the yield strength of the beam framing into the joint, experimental data indicates that drift history also affects strength deterioration of joints [2]. The results of previous research suggest also that in addition to material properties and geometric configuration a number of different design parameters may affect joint response. These design parameters include column axial load, joint shear stress demand, joint longitudinal reinforcement ratio, joint shear reinforcement ratio, etc. [3]. Researchers have tried to propose new models which can correctly be modeled as joints in frame, meanwhile remaining a simple, easily applied, computationally efficient model that the engineer can use to assess the potential for non-ductile joint response, and thereby need for further investigation using a more sophisticated and time consuming analysis methods [4-6].

NURBS based on B-spline functions is one of the most employed curve or surface fitting models, provided that it is a standard representation of curves and surfaces, and is widely supported by modern standards like OpenGL and IGES, which are used for geometric data exchange. In order to find a good NURBS model from a large pool of data, the control points and weights are generally respected as variables [7]. Many practical surface reconstruction techniques based on measured data points require the solution of optimization of problems in fitting surface data. In the binary-coded genetic algorithm (GA) used for control point optimization, knot value optimization and error minimization of parametric surfaces as a global optimization problem is shown. GA is the heuristic method and optimization technique that mimics the process of natural evolution [7]. B-splines are polynomial curves; they are flexible and offer many useful properties for the design of a curve or a surface. It is worth mentioning that B-spline functions are widely used in computer-aided engineering and computer-aided manufacturing. From the point of introducing rational homogeneous coordinates in B-spline curves are derived the definition of NURBS, which is called a non-uniform rational B-spline. In addition, the NURBS surface model has stability, flexibility, local modification properties, and is robust to noise [8].

In this paper, an approximation technique based on NURBS surface by GA for achieving seismic response surface (SRS) of RC joints is presented. Approximation techniques in this context usually involve fitting a curve or surface through a set of data points which is subjected to some error. This current work describes joint mechanics by considering site effects on destructions of beam-column joints under seismic motions using SRS exhibition. For this reason, three experimental models have been selected to calibrate a model of joints. Step-by-step nonlinear FEM analysis is used. The 
necessary flexibility coefficients are formulated on a member-by-member basis. Then, a response of four analytical joint models subjected to different seismic waves is computed. The next step is to evaluate NURBS surface fitting from the results obtained by a GA on the control points, which may be solved through the given scattered points calculated by analytical models. Numerical and graphical results are provided, demonstrating that the present method produces a valid SRS with low-fitting error. The applicability of this method is validated with respect to the estimation deterioration displacement of the RC joints under the effect of different input seismic motions and site classes.

\section{SURFACE FITTING WITH NURBS}

\subsection{NURBS SURFACE}

Non-uniform Rational B-splines (NURBS) are widely using parametric approximation curves or surfaces. Sometimes, mathematical properties of NURBS are used in simulations. The goal of this section is a simulation of the seismic response curve in beam-column joints under earthquake loading with different tectonic characteristics. A B-spline is an approximation of the spline exhibiting local control points such as Bezier curves, and surfaces allowing greater shape control through the use of weights $\omega_{i, j}$ (described in [9]). The definition of NURBS surface is

(1.2) $g(u, v)=\left(\begin{array}{l}g\left(u_{1}, v_{1}\right) \\ g\left(u_{2}, v_{2}\right) \\ g\left(u_{3}, v_{3}\right)\end{array}\right)=\frac{\sum_{i=0}^{n} \sum_{j=0}^{m} N_{i, d_{u}}(u) N_{j, d_{v}}(v) \omega_{i, j} p_{i, j}}{\sum_{i=0}^{n} \sum_{j=0}^{m} N_{i, d_{u}}(u) N_{j, d_{v}}(v) \omega_{i, j}} \omega_{i, j}>0 \quad 0 \leq u, v \leq 1$

where $N_{i, d}(u)$ and $N_{j, d}(u)$ are the basis functions and $p_{i, j}$ are the local control points. The simplest definition for the basis function is recursive and is given by

(3.2) $N_{k, d}(u)=\frac{u-\mu_{k}}{\mu_{k+d}-\mu_{k}} N_{k, d-1}(u)+\frac{\mu_{k+d+1}-u}{\mu_{k+d+1}-\mu_{k+1}} N_{k+1, d-1}(u)$

(4.2) $\mu=\left\{0, \ldots, 0, \mu_{d_{u}+1}, \ldots, \mu_{r-d_{u}-1}, 1, \ldots, 1\right\} r=n+d_{u}+13$ 
where $d_{u}=d_{v}=3$ is the degree and $\mu$ is a knot-vector. The resulting value can be obtained at parameters $u, v$.

\subsubsection{OPTIMIZATION OF A NURBS SURFACE}

The problem of fitting a surface to measured data such as seismic responses of structures can be posed as an optimization problem. For this reason, let $g(u, v)$ be a parametric surface and consider the problem of fitting $g(u, v)$ to measured points $\widetilde{g}_{1}, \widetilde{g}_{2}, \ldots, \widetilde{g}_{m}$ so that the sum of the square of the distances to points $g\left(u_{1}, v_{1}\right), g\left(u_{2}, v_{2}\right), \ldots, g\left(u_{m}, v_{m}\right)$ on the surface is minimized. If through Eq. (1.2) all weights are equal, the NURBS surface is a B-spline surface as follow,

$$
g(u, v)=\left(\begin{array}{l}
g\left(u_{1}, v_{1}\right) \\
g\left(u_{2}, v_{2}\right) \\
g\left(u_{3}, v_{3}\right)
\end{array}\right)=\sum_{i=0}^{n} \sum_{j=0}^{m} N_{i}(u) N_{j}(v) p_{i, j}
$$

where the local control points are included linearly. Then, the fitting data points using NURBS attempt to minimize the fitness function as follows,

$$
\min _{p} \sum_{l=1}^{p}\|g-\widetilde{g}\|^{2}
$$

where $p$ is the number of local control points. This formula is solved three times, once for each dimension. Through this use of GA, optimization of both the knots and the weights corresponding to the control points for surface fitting is completed. In this study, GA uses the mutation and crossover functions to produce new individuals at every generation. This means that a whole new population of feasible points is reproduced by selecting the best representatives of the previous generation points, crossing them, and obtaining a new set of individuals. This new generation now has better characteristics than the good members of the previous generation, per Popov and Rotkov [7]. 


\section{VALIDATION PROCEDURE}

The results of previous experimental tests of joints were reviewed to assemble a data set to be used in investigating the seismic response of beam-column joints and evaluating and validating the $3 \mathrm{D}$ analytical models. The subassemblies of the beam-column joint specimens are shown in Fig. 1.
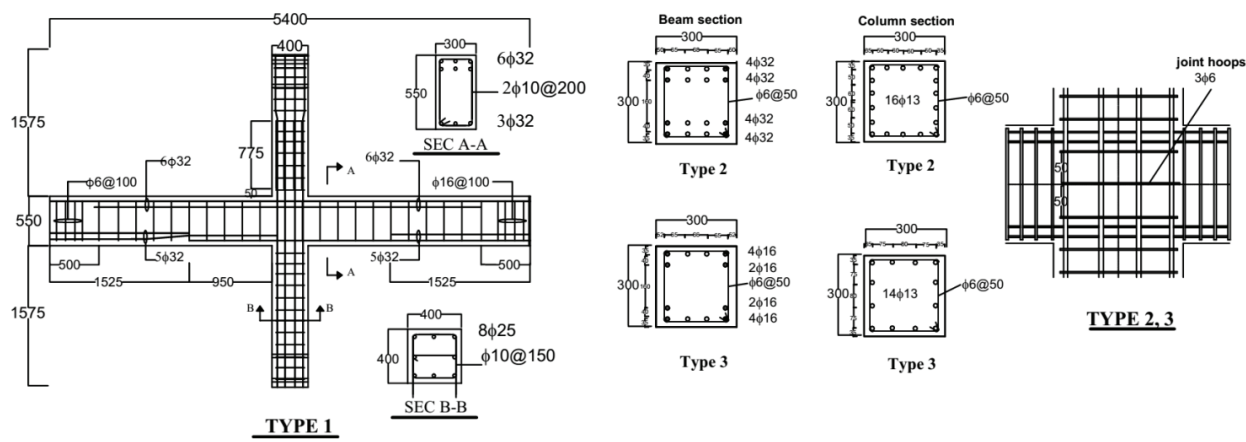

TYPE 2,3

Fig. 1.Beam-column joint specimens subassemblies

A finite element model (FEM) for simulating the tested beam-column joints subjected to cyclic loading by using the general purpose finite element program ANSYS is presented. The concrete was modelled using an eight-node solid element (SOLID 65) capable of handling cracking, tension stiffening, the shear capacity of cracked concrete, and crushing in compression. The reinforcing steel bars were modelled with a series of two-node link elements (LINK 8). For modelling the bars, a flow rule using the vonMises yield criterion was adopted. The embedded constraint was applied between the reinforcement bars and the concrete components.

\subsection{EXPERIMENTAL SPECIMEN - TYPE 1}

As shown in Fig. 1, the selected topology of the Type 1 specimen does not have any horizontal or vertical transverse reinforcement in the panel zone region [4]. This specimen was subjected to a lateral load at the column-top. In quasi-static tests on the beam-column subassembly, cyclic loadings can either be applied to the column-top or at the beam-tips (this does not include P-delta effects) while keeping the other fixed supports. Boundary conditions were simulated with precision in the experimental test of the horizontal and vertical restraints, representing a pin connection applied to the bottom of the column. The reverse-direction displacements were applied to simulate cyclic load 7 
conditions at the two beam-tips. An incremental/iterative solution procedure is essential because the characteristic of the adapted element is nonlinear. Further experimental results are studied in compression with analytical results for beam-column joints. Fig. 2 shows the load-deformation curves for a Type 1 specimen under cyclic loading. Here, the load (column shear) is the horizontal reaction force recorded by the load cell at the column-top, and the deformation (drift) is the angle made by the line joining the beam-tips with respect to the original beam axis.
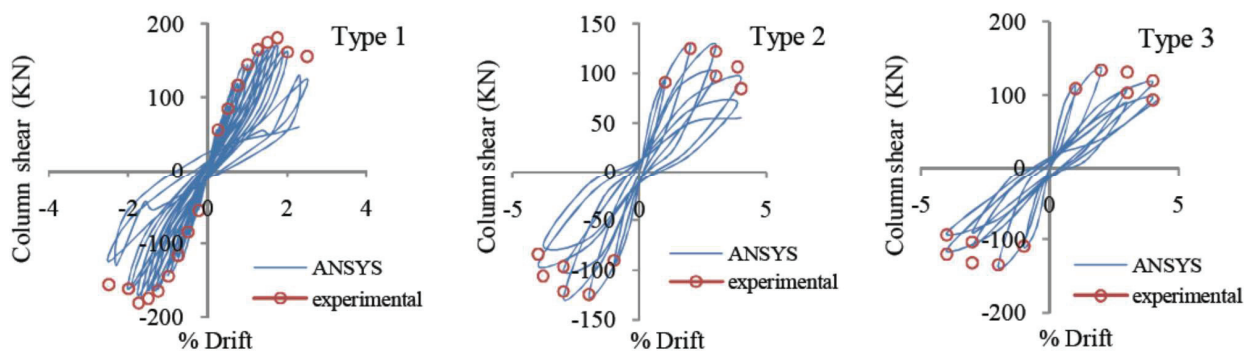

Fig.2.Best simulation of load-deformation data for Type 1, 2, and 3 specimens

It can be seen that there was an initial elastic response and the load-deformation curve is closely linear. Following this, the stiffness gradually degraded and the behavior of the specimen entered the inelastic range. With increasing displacement, pinch effects are observed explicitly in the hysteretic loops, which are caused by the closing and opening of cracks or the debonding of the steel bars. Good correlation between observed and simulated column shear-deformation responses could be observed in Fig. 2, but could not be obtained in the post-peak region.

\subsection{EXPERIMENTAL SPECIMENS TYPE 2 AND 3}

Two specimens, Type 2 and 3(see details in Fig. 1), have been selected respectively from experiments of the A and D specimen series conducted by Kusuhara and Shiohara [5]. The boundary conditions in the two end of the beam have roller support, and the top end of the column was also connected to a horizontal actuator through a universal-pin joint. 
Table 1. Characteristics of considered joints' different states

\begin{tabular}{|c|c|c|c|c|c|c|}
\hline \multicolumn{3}{|c|}{ Joints type } & B1 & B2 & B3 & B4 7 \\
\hline \multicolumn{3}{|c|}{ Concrete compressive strength (MPa) } & 28.3 & 30.4 & 32.7 & 32.7 \\
\hline \multicolumn{3}{|c|}{ Tensile splitting strength (MPa) } & \multicolumn{4}{|c|}{2.9} \\
\hline \multicolumn{3}{|c|}{ Yield strength (MPa) } & \multicolumn{4}{|c|}{537} \\
\hline \multirow{6}{*}{ 壱 } & \multicolumn{2}{|c|}{ Depth $\mathrm{x}$ width $\mathrm{mm}$} & $300 \times 300$ & $300 \times 300$ & $300 \times 500$ & $400 \times 400$ \\
\hline & \multirow{2}{*}{ Longitudinal bars } & Top & $5 \varnothing 14$ & $5 \varnothing 14$ & $5 \varnothing 22$ & $6 \varnothing 24$ \\
\hline & & Bottom & $5 \varnothing 14$ & $8 \varnothing 14$ & $7 \varnothing 22$ & $7 \varnothing 24$ \\
\hline & \multicolumn{2}{|c|}{ Transverse bars } & Ø6@50 & Ø8@ @50 & $\varnothing 10 @ 50$ & Ø10@50 \\
\hline & \multicolumn{2}{|c|}{ Transverse bars angle } & 45 & 90 & 45 & 90 \\
\hline & \multicolumn{2}{|c|}{ Tensile bars ratio } & 1 & 1.6 & 2 & 2.3 \\
\hline \multirow{4}{*}{ 当 } & \multicolumn{2}{|c|}{ width $\times$ Depth $\mathrm{mm}$} & $300 \times 300$ & $500 \times 500$ & $300 \times 300$ & $400 \times 400$ \\
\hline & \multicolumn{2}{|c|}{ Longitudinal bars } & $14 \varnothing 14$ & $16 \varnothing 24$ & $16 \varnothing 16$ & $16 \varnothing 22$ \\
\hline & \multicolumn{2}{|c|}{ Transverse bars } & Ø10@50 & Ø10@50 & $\varnothing 12 @ 50$ & Ø12@50 \\
\hline & \multicolumn{2}{|c|}{ Bars ratio } & 2.4 & 2.8 & 3.6 & 3.8 \\
\hline \multicolumn{3}{|c|}{ Joint Transverse bars } & Ø10@50 & $\varnothing 10 @ 50$ & & \\
\hline \multicolumn{3}{|c|}{ Column to beam depth ratio } & 1 & 1.7 & 0.6 & 1 \\
\hline
\end{tabular}

Fig. 2 shows simulated and observed column shear-deformation responses of Type 2 and 3 specimens, respectively. Good correlation can be observed in the pre-peak region. The simulated loaddeformation response was observed not to be softened after the observed peak strength was achieved.

\section{AnAlytical MODels}

As shown in Table 1, four analytical models were created and different classes of site conditions (see Fig. 3) were defined. In the following, various conditions have been studied through the composition of these specimens. Finally, regarding obtained results of studied joints finite components analysis and with considering the influence of effective parameters (site class and tectonics characteristic) on proposed joint behavior, some suggestion can be presented for obtaining the joint maximum flexibility. In Table 1, a state is considered for basis joints in which a minimum to maximum percentage of recommendations allow tensional reinforcement, various percentages of different transverse reinforcements, and columns and beams in different dimensions have been used.
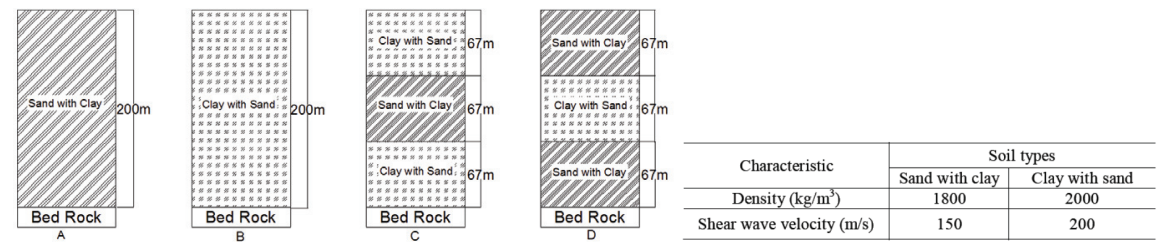

Fig. 3. Different classes of considered site 
Previously registered earthquakes with different tectonics characteristic have been used for this purpose, their magnitudes have been calculated based on the estimations of their seismic moments. Details of these records are given in Table 2.

Table 2. Details of ground motion ensemble

\begin{tabular}{|c|c|c|c|c|c|c|c|c|c|}
\hline ž & $\underset{\mathbb{8}}{\stackrel{\leftrightarrow}{\sharp}}$ & Earthquake & $M_{W}$ & Mech. $^{\text {a }}$ & $\begin{array}{l}\text { Recording } \\
\text { station }\end{array}$ & $\begin{array}{l}\text { Dist. } \\
(\mathrm{km})\end{array}$ & $\begin{array}{l}\text { Site } \\
\text { class } b\end{array}$ & Comp. & $\begin{array}{c}\text { PGA } \\
(\mathrm{g})\end{array}$ \\
\hline \multicolumn{10}{|c|}{ Far-fault ground motions } \\
\hline 1 & 1989 & Loma Prieta & 7.0 & OB & Presidio & 67.4 & $\mathrm{D}$ & 090 & 0.10 \\
\hline \multicolumn{10}{|c|}{ Near-fault ground motions with forward directivity } \\
\hline 2 & 1995 & Kobe & 7.4 & SS & KJMA & 0.6 & $\mathrm{C}$ & 000 & 0.82 \\
\hline \multicolumn{10}{|c|}{ d motions with fling step } \\
\hline 3 & 1999 & Chi-Chi & 7.6 & TH & TCU074 & 13.8 & $\mathrm{D}$ & EW & 0.59 \\
\hline \multicolumn{10}{|c|}{ Summary: } \\
\hline Sum & ry: & ${ }^{\mathrm{b}} \mathrm{NEHRP}$ Site $\mathrm{cl}$ & for $\mathbf{V}$ & $=360-7$ & $\mathrm{a} / \mathrm{s} ; \mathrm{D}$ for $\mathrm{V}$ & $0-3$ & & & \\
\hline
\end{tabular}

To facilitate comparison with dynamic analyses, the selected earthquakes are scaled. Three dimensional models of the $\mathrm{B} 1, \mathrm{~B} 2, \mathrm{~B} 3$, and $\mathrm{B} 4$ specimens subjected to the scaled earthquakes are developed using nonlinear finite element modelling in ANSYS. Concrete and reinforcement element types are SOLID 65 and LINK 8, respectively. Reinforcement bars are embedded in concrete in the models. According to the results of various site class analysis in software, it is necessary to mention that the existence of soil layers changes the ground motion records. Generally, ground motion is exacerbated with the increase of the lower layers' plasticity rate, which causes more deformations in structural components. In all cases, the load-deformation curves are obtained completely, and then a limited amount of data included in the deterioration displacements (called local control points)is selected from the load-deformation curves of the four specimens under earthquake influence. The local control points are one of the important domains which are applied in the next simulation process step (chapter 5).It should also be noted that the nonlinear FEM can accurately predict the loaddeformation curves of the analytical models. However, the models are quite complicated and the analysis is very time-consuming because different types and excessive numbers of elements and contacts are included. 


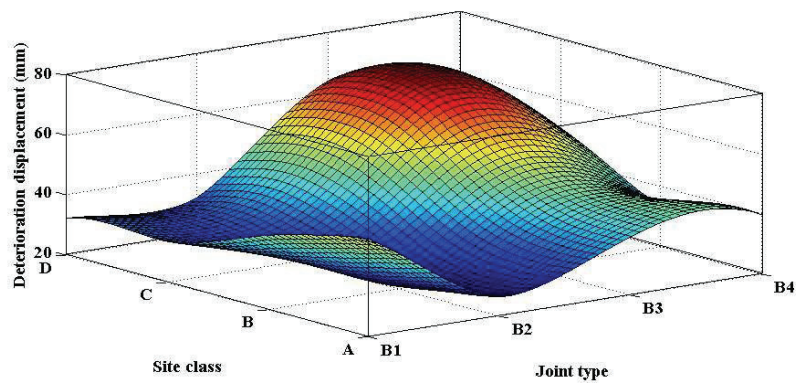

Fig. 4. Generated SRS for the beam-column joints under far fault

\section{SIMULATION OF SRS WITH NURBS SURFACE FITTING}

The parameters of the SRS which are to predict seismic response are usually determined by a NURBS surface by fitting values to existing analytical data points. The method for constructing NURBS surfaces fitting from scattered and unorganized point of a SRS is made up roughly of two stages: the first regularizes and fits the NURBS surface, and the second optimizes the NURBS surface fitting and trims the surface in order to eliminate points inserted outside the SRS during the regularization process. Local control points are selected from the results of nonlinear FEM. The GA optimization process with a population size of 30 and a generation of 50 is after a fitting procedure using the NURBS method. In Figs. 4-6 it can be seen that the NURBS surface fitting obtained by GA approximation of the response surface is able to represent sudden changes in the SRS's behavior. The resulting surfaces show that the seismic response (deterioration displacement) occurs at the BeamColumn Joints under different site classes and earthquakes.

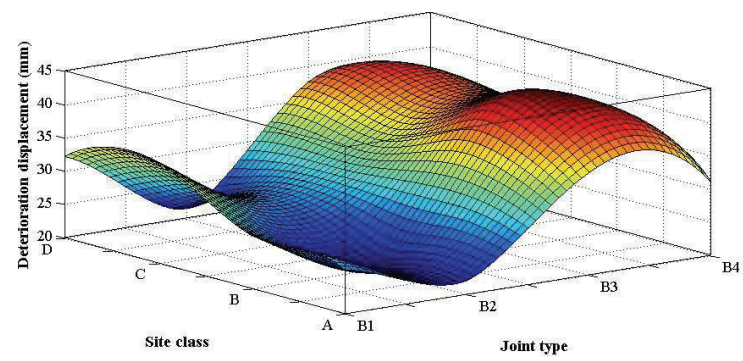

Fig. 5. Generated SRS for the beam-column joints under near-fault (forward-rupture directivity) 


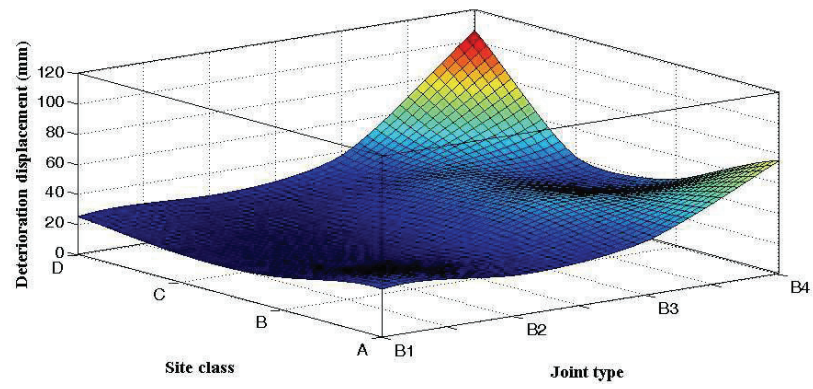

Fig. 6. Generated SRS for the beam-column joints under near-fault (fling-step)

The sum of the squares due to error (SSE) measures the total deviation of the response values from the surface fit to the response values. This statistic measurement of the distribution with respect to the NURBS simulation is presented. Although the accuracy improves with the number of sample points, the proposed NURBS-based method leads to the lowest errors. The SRS surfaces were generated using the computed maximum deterioration displacement at joints, and the three performance levels are listed in Table 3.

Table 3. The best NURBS fitting of some generations

\begin{tabular}{ccccc}
\hline No & Earthquake & $\begin{array}{c}\text { Number of } \\
\text { function } \\
\text { evaluations }\end{array}$ & $\begin{array}{c}\text { Best } \\
\text { fitness }\end{array}$ & SSE \\
\hline 1 & far fault & 1530 & -52.430 & $4.985 \mathrm{e}-27$ \\
\hline 2 & $\begin{array}{c}\text { near-fault (forward- } \\
\text { rupture directivity) }\end{array}$ & 1530 & -43.369 & $1.528 \mathrm{e}-27$ \\
\hline 3 & $\begin{array}{c}\text { near-fault } \\
\text { (fling step) }\end{array}$ & 1530 & -357.685 & $1.058 \mathrm{e}-26$ \\
\hline
\end{tabular}

The SRS surfaces of analytical models have confirmed that the ultimate tolerable seismic load and the joint failure in lateral displacement are different in various site classes. Furthermore, Figs. 4-6 reveal the distribution of the maximum lateral displacements relative to the joints for the four site classes under three tectonic characteristic levels. For instance, as shown in Fig. 6, the maximum deterioration displacement is obtained from analysis at the B4 joint under near-fault with a fling step. It should also be noted here that an upper limit to the amount of joint reinforcement was identified by previous researchers; beyond it the overall resistance of the beam-column joint assemblies is not improved. 


\section{CONCLUSION}

In the present paper, an approximation method based on NURBS surface fitting by GA to achieve a seismic response surface (SRS) of reinforced concrete beam-column joints is proposed. Local control points such as seismic response are obtained by using nonlinear dynamic analysis of four analytical models. NURBS surface fitting is achieved to the control points, which may be solved on the given scattered points. Furthermore, the optimization method based on a GA was performed to evaluate the accuracy and speed with which the response could recover known contact quantities. The comparison is performed with respect to the deterioration displacement of reinforced concrete beam-column joints under different site classes observed from the SRS. The results have shown that an approximation of the response leads to an accurate estimation of the analytical models. Moreover, the error decreases remarkably as the number of sampling points is increased. More results of the present research include the fact that earthquakes lead to widespread destruction in special regions and small destruction in other regions, showing the importance of site class effects. As it is concluded from the results of the B3 and B4 joints, because of those structures being so hard, they rarely show proper behavior. The simulations using NURBS fitting results have shown that for all joint types analytical lateral displacements obtained from the dynamic analysis are quite similar to those obtained from the SRS surfaces. The predictions for the failure modes and the ultimate ductility capacities correlate well with the analytical results. This trend lends support to the use of computational modelling techniques.

\section{REFERENCES}

1. B.Li, Y.Wu and T.C. Pan, "Seismic behavior of nonseismically detailed interior beam-wide column joints-Part II: Theoretical Comparisons and Analytical Studies", ACI Structural Journal, 100(6): 56-65, 2003.

2. H. Shiohara and F. Kusuhara, "An overlooked failure mechanism of reinforced concrete beam-column joints" Proceedings of the 9th U.S. National and 10th Canadian Conference on Earthquake Engineering, Toronto, July, 2010.

3. L.N. Lowes and A. Altoontash, "Modeling reinforced-concrete beam-column joints subjected to cyclic loading", ASCE Journal of Structural Engineering, 129(12): 1686-1697, 2003.

4. R.P. Dhakal, P. Tso-Chien, P. Irawan and T. Keh-Chyuan, "Experimental study on the dynamic response of gravity-designed reinforced concrete connections", Engineering Structures, 27(1): 75-87, 2005.

5. F. Kusuhara and H. Shiohara, "Tests of R/C beam-column joint with variant boundary conditions and irregular details on anchorage of beam bars", The 14th World Conference on Earthquake Engineering, Beijing, China, October, 2008.

6. B. Li, E. Lam, B. Wu and Y. Wang, "Effect of High Axial Load on Seismic Behavior of Reinforced Concrete Beam-Column Joints with and without Strengthening", ACI Structural Journal, 112(6): 713-724, 2015. 1 
7. E.V. Popov and S.I. Rotkov, "The retrieval of NURBS-surface by genetic algorithm on the basis of point cloud", 21st International Conference in Central Europe on Computer Graphics, Visualization and Computer Vision (WSCG) Communication Papers Proceedings, Plzen, Czech, June, 2013.

8. I. Park, I. Yun and S. Lee, "Constructing NURBS surface model from scattered and unorganized range data", In Second International Conference on 3-D Digital Imaging and Modeling, Ottawa, Canada, July, 1999.

9. B. Gregorski, B. Hamann and K. Joy, "Reconstruction of B-spline surfaces from scattered data points", In Proceedings of Computer Graphics International, Geneva, Switzerland, 2000.

\section{LIST OF FIGURES AND TABLES:}

Fig. 1. Beam-column joint specimens subassemblies

Rys. 1. Podzespoły próbek łączników belkowo-słupowych

Fig. 2. Best simulation of load-deformation data for specimens Type 1,2 and 3

Rys. 2. Optymalna symulacja danych dotyczących obciążenia i odkształcenia z zakresie próbek typu 1, 2 i 3

Fig. 3. Different classes of considered site

Rys. 3. Różne klasy rozpatrywanego miejsca

Fig. 4. Generated SRS for the beam-column joints under far fault

Rys. 4. Wygenerowane SRS dla łączników belkowo-słupowych w strefie uskokowej

Fig. 5. Generated SRS for the beam-column joints under near-fault (forward-rupture directivity)

Rys. 5. Wygenerowane SRS dla łączników belkowo-słupowych w strefie przyuskokowej (w kierunku zerwania)

Fig. 6. Generated SRS for the beam-column joints under near-fault (fling-step)

Rys. 6. Wygenerowane SRS dla łączników belkowo-słupowych w strefie przyuskokowej (zarzucenie)

Tab. 1. Characteristics of considered joints' different states

Tab. 1. Charakterystyka różnych stanów rozpatrywanych łączników

Tab. 2. Details of ground motion ensemble

Tab. 2. Informacje szczegółowe dotyczące zespołu ruchu naziemnego

Tab. 3. The best NURBS fitting of some generations

Tab. 3. Najlepsze dopasowanie NURBS w zakresie niektórych generacji 


\section{SYMULACJA REAKCJI SEJSMICZNEJ LĄCZNIKÓW BELKOWO-SŁUPOWYCH WYKONANYCH Z BETONU ZBROJONEGO Z DOSTOSOWANIEM POWIERZCHNI NURBS}

Slowa kluczowe: krzywa B-sklejana, NURBS, powierzchnia reakcji sejsmicznej (SRS), łącznik RC, model analityczny, algorytm genetyczny, właściwości tektoniczne

\section{STRESZCZENIE:}

W niniejszej pracy przedstawiono technikę aproksymacji, opartą na niejednorodnych powierzchniach krzywych Bsklejanych (NURBS), z wykorzystaniem algorytmu genetycznego (GA), w celu uzyskania powierzchni reakcji sejsmicznej (SRS) łączników belkowo-słupowych wykonanych z betonu zbrojonego (RC). NURBS oparta na algorytmie genetycznym jest ważnym narzędziem matematycznym i składa się z uogólnień krzywych i powierzchni Beziera oraz krzywych B-sklejanych. Techniki aproksymacji w tym kontekście zwykle obejmują dostosowanie krzywej lub powierzchni za pośrednictwem zestawu punktów danych, które są narażone na pewne błędy. Ogólnie rzecz biorąc, dokładność procesu projektowania łączników belkowo-słupowych zależy od liczby punktów kontrolnych pozyskanych z wyników badań eksperymentalnych prowadzonych na rzeczywistych próbkach. Oczywistym jest fakt, że wartości mierzone na rzeczywistych próbkach są najlepszymi narzędziami do wykorzystania w analizie sejsmicznej, przy czym są jednak droższe w porównaniu do wartości symulowanych przez SRS. SRS zaproponowane w niniejszej pracy można zastosować w celu uzyskania powierzchni, które oceniały wpływ lokalizacji na zniszczenia łącznika belkowo-słupowego, biorąc pod uwagę różne warunki lokalizacyjne dla określonego trzęsienia ziemi. $Z$ tego powodu dokonano wyboru trzech modeli eksperymentalnych, w celu zatwierdzenia modelu łączników. Krok po kroku zastosowano nieliniową analizę FEM. Niezbędne współczynniki elastyczności zostały opracowane na podstawie metody poszczególnych członków. Następnie obliczono reakcję czterech modeli analitycznych, poddanych różnym falom sejsmicznym. Kolejnym krokiem była ocena dostosowania powierzchni NURBS na podstawie wyników uzyskanych przez GA w punktach kontrolnych, które mogą być rozwiązane w podanych rozproszonych punktach, obliczonych na podstawie modeli analitycznych. Zaprezentowano liczbowe i graficzne wyniki, które wskazywały, że aktualna metoda generuje prawidłowe SRS z błędnym dostosowaniem. Możliwość zastosowania tej metody została potwierdzona w odniesieniu do pogorszenia szacunków dotyczących łączników RC pod wpływem różnych wejściowych ruchów sejsmicznych i klas lokalizacji.

\section{Procedura zatwierdzenia}

Wyniki poprzednich badań eksperymentalnych w zakresie łączników zostały przeanalizowane w celu zgromadzenia zestawu danych do wykorzystania w badaniu reakcji sejsmicznej łączników belkowo-słupowych, wykonanych z betonu zbrojonego oraz w ocenie i zatwierdzeniu modeli analitycznych 3D. Zestaw danych składa się z trzech próbek dwuwymiarowych wewnętrznych łączników RC, realizowanych przez dwa zespoły badawcze. Z tego powodu zaprezentowano model elementów skończonych (FEM), służący do symulacji badanych łączników RC, poddawanych cyklicznemu obciążeniu z wykorzystaniem ogólnego programu elementów skończonych (ANSYS). Modelowanie betonu zostało przeprowadzone przy użyciu ośmiowęzłowego ciała stałego (SOLID 65), zdolnego do radzenia sobie z pękaniem i usztywnieniem oraz posiadającego zdolność ścinania pękniętego betonu oraz kruszenia przy ściskaniu. Stalowe pręty zbrojeniowe zostały poddane modelowaniu z wykorzystaniem szeregu dwuwęzłowych elementów łączących (LINK 8). $\mathrm{W}$ odniesieniu do modelowania prętów zastosowano regułę przepływu z wykorzystaniem kryterium von-Mises. Zastosowano ograniczenie dla obszaru pomiędzy prętami zbrojeniowymi i elementami betonowymi. 3 


\section{Modele analityczne}

Niniejszy punkt został poświęcony czterem modelom analitycznym oraz różnym klasom warunków lokalizacyjnych. W dalszej części zbadano różne warunki z wykorzystaniem składu opisanych próbek. Ostatecznie wykorzystano uzyskane wyniki analizy badanych elementów skończonych łączników oraz wpływ skutecznych parametrów (klasa lokalizacji i właściwości tektoniczne) na zaproponowaną reakcję łącznika wykonanego z betonu zbrojonego. Jednakże, przedstawione modele analityczne będą musiały zmierzyć się z niektórymi poważnymi problemami dotyczącymi symulacji efektów uciskania oraz degradacji siły i sztywności w pętlach histeretycznych.

\section{Symulacja SRS z dostosowaniem powierzchni NURBS}

Parametry SRS, które mają przewidywać reakcję sejsmiczną, są zwykle obliczane na podstawie powierzchni NURBS poprzez dostosowanie wartości do istniejących punktów danych analitycznych. Metoda dostosowywania powierzchni NURBS na podstawie rozproszonych i niezorganizowanych punktów SRS obejmuje dwa etapy. Pierwszy z nich reguluje i dostosowuje powierzchnię NURBS. Drugi etap optymalizuje dostosowanie powierzchni NURBS i zmniejsza powierzchnię w celu wyeliminowania punktów umieszczonych poza SRS podczas procesu regularyzacji. Proces optymalizacji GA o wielkości populacji na poziomie 30 i wielkości generacji na poziomie 50 jest realizowany po ukończeniu procedury dostosowywania z wykorzystaniem metody NURBS. Na podstawie Rysunków 4-6 można zauważyć, że dostosowanie powierzchni NURBS za pośrednictwem aproksymacji GA w zakresie powierzchni reakcji może być związane z nagłą zmianą reakcji SRS. Należy zauważyć, że na podstawie przedstawionych wyników reakcja sejsmiczna występuje na Łącznikach Belkowo-Słupowych w różnych klasach lokalizacji i trzęsieniach ziemi.

Suma kwadratów będących wynikiem błędu (SEE) jest odpowiedzialna za pomiar całkowitego odchylenia wartości reakcji od powierzchni dostosowanej do wartości reakcji. Przedstawiono statyczny pomiar rozkładu w odniesieniu do symulacji NURBS. Pomimo, że dokładność ulega poprawie wraz z liczbą punktów poboru próbek, zaproponowana metoda oparta na NURBS prowadzi do mniejszych błędów.

Porównanie jest przeprowadzane w odniesieniu do pogorszonego przemieszczenia łączników belkowo-słupowych wykonanych $\mathrm{z}$ betonu zbrojonego o różnych klasach lokalizacji, obserwowanych z SRS. Wyniki pokazały, że aproksymacja reakcji prowadzi do dokładnego oszacowania modeli analitycznych. Ponadto, błąd ulega znacznemu zmniejszeniu wraz ze wzrostem liczby punktów poboru próbek. Większa ilość wyników obecnych badań przemawia za tym, że trzęsienia ziemi prowadzą do ogromnych zniszczeń w specjalnych regionach i niewielkich zniszczeń w innych regionach, ukazując znaczenie wpływów klas lokalizacji. W oparciu o wyniki łączników B3 i B4, struktury te rzadko wykazują prawidłową reakcję ze względu na swoją twardość. Symulacja z zastosowaniem wyników dostosowania NURBS wykazała, że w odniesieniu do wszystkich typów łączników, analityczne przesunięcie poprzeczne, uzyskane na podstawie analizy dynamicznej, jest dość podobne do tych uzyskanych na podstawie powierzchni SRS. Prognozy dotyczące uszkodzeń i plastyczności dobrze korelują z wynikami analitycznymi. Tendencja ta przemawia za stosowaniem technik modelowania komputerowego. 